\title{
A voz da dignidade em $O$ que os cegos estão sonhando? de Noemi Jaffe
}

\author{
Fábio Waki*
}

\section{Um breve excurso sobre a dignidade humana}

Há alguns meses tenho por hábito tirar os sábados para almoçar em um pequeno restaurante próximo de onde vivo, em Coimbra; embora seja uma tasca tipicamente portuguesa, aonde vou para desfrutar de um prato também tipicamente português, o lugar é administrado por um casal de refugiados sírios. Com o tempo, a minha assiduidade ali, e o fato de que sempre tenho comigo um livro para ler, permitiu que se formasse entre mim e esse casal alguma intimidade, a ponto de que eles se sentissem confortáveis para me perguntar o que, enfim, eu estudo na universidade. Ainda que eu me esforçasse para lhes explicar com palavras simples em que exatamente minha pesquisa consistia, logo ficou claro que eram eles, na verdade, quem mais tinham interesse em encontrar palavras para me explicar sobre a vida deles antes da Europa.

Como vim descobrir, Abdul, o marido, era engenheiro químico em uma fábrica de derivados de petróleo, enquanto Dina, sua esposa, era professora de biologia no que acredito ser o ensino médio. Embora nada haja de vergonhoso em servir mesas, saber que um engenheiro químico e uma professora de biologia eram, resignadamente, os responsáveis por trazer à minha mesa o meu pedido de sempre me fez sentir por eles um certo pesar - um sentimento nada comparado, porém, com o pesar que senti ao perceber a ênfase que Dina dava ao pretérito para se referir à sua vida na Síria: ela era professora de biologia; seu marido era engenheiro químico. Essa revelação me levou a uma pergunta óbvia, mas para cuja resposta eu não estava preparado; eu perguntei de onde, afinal, eles vinham na Síria - e a resposta da mulher, por trás de um largo sorriso, não foi mais do que uma simples palavra: "Aleppo." Ao ouvir a resposta da esposa, Abdul, que até então tinha as costas viradas para nós, deixou escapar uma risada - e a reação da mulher, mais uma vez para a minha surpresa, foi a de rir junto. O português de Abdul não é tão bom quanto o de Dina, então talvez só com essa palavra ele tivesse realmente compreendido o teor da nossa conversa; mas creio que não, creio que ele tinha

Doutorando em Materialidades da Literatura na Universidade de Coimbra, Coimbra, Portugal. Email: fabwaki@gmail.com. 
acompanhado nossa conversa desde o início, e sua risada era mesmo a única reação possível ao que tal palavra significa.

Dina e Abdul não são os primeiros refugiados com quem tive contato: ainda no Brasil, eu tive a oportunidade de conhecer outros refugiados sírios, mas esses tinham deixado o país porque suas terras tinham sido isoladas por corredores de controle militar; vários anos atrás, na Unicamp, minha alma mater, pude fazer amizade com estudantes haitianos, impelidos a sair do seu país por conta de um terrível desastre natural; em Estocolmo, onde completei parte do meu doutorado, eu acabei por conviver com várias famílias fugidas do norte da África, expulsas dos seus países por causa da proximidade de conflitos armados ou por causa de uma escassez de recursos cada vez mais grave. No entanto, que duas pessoas tão centrais nos meus dias fossem vítimas e testemunhas em primeira mão de uma das mais terríveis zonas de guerra na Ásia foi uma notícia que não pude receber sem alguma perplexidade - algo que não passou despercebido a Dina. Ao notar que eu não sabia como reagir a tal informação, ela deu de ombros, abriu um novo sorriso e, olhando para o restaurante ao nosso redor, apenas confirmou: "Sim, nós somos de Aleppo". Dessa vez, porém, sua voz e seu sorriso tinham uma jovialidade um tanto diferente, não a jovialidade tragicômica da primeira resposta, mas uma jovialidade triste e condescendente: "Sim, nós somos de Aleppo, e se não tivéssemos saído de lá em tempo, provavelmente estaríamos mortos", foi o que Dina realmente pareceu querer me dizer. A partir dessa conversa, foi como se eu os tivesse vendo ali pela primeira vez, foi como se eu os estivesse conhecendo naquele momento - porque de fato eu estava: para mim, eles subitamente deixaram de ser o humilde casal de comerciantes sírios, alocados em uma cidade no centro de Portugal para exercer uma atividade que eles sempre tinham exercido, e se revelaram como a antiga professora de biologia e o antigo engenheiro químico, destituídos de tudo e de todos, pessoas para quem a violência, a miséria e o horror da guerra tinham se mostrado tão absurdos, tão inefáveis, a ponto de virem a ser, simplesmente, risíveis.

Creio que o principal motivo pelo qual tais eventos ficaram tão bem registrados na minha memória tenha a ver com o fato de que eles em muito me lembram do ensaio "A quem pertence Auschwitz?", ${ }^{1}$ do escritor húngaro Imre Kertész (19292016). Sobrevivente de Auschwitz e de Buchenwald, Kertész debate nesse ensaio o que deverá ser feito da memória do Holocausto à medida em que sobreviventes como ele forem perecendo, levando consigo os testemunhos em primeira mão da barbárie nazista.

Por fim, a proposta de Kertész é relativamente simples: para ele, a inefabilidade intrínseca à experiência da barbárie faz com que essa experiência só possa ser imaginada - inclusive, e na verdade sobretudo, por parte dos sobreviventes dessa barbárie; na medida em que essa experiência só pode ser imaginada, as artes, em particular a literatura, se tornam mediações fundamentais para um entendimento mí-

\footnotetext{
No original, "Wem gehört Auschwitz?", publicado no periódico hamburguês Die Zeit em novembro de 1998. Utilizo a versão em inglês, "Who owns Auschwitz?" (ver Kertész, 2001).
} 
nimo, ainda que sempre imperfeito, dessa experiência; mas, uma vez que não há justiça possível na compreensão efetiva de um sofrimento alheio, isto é, uma vez que não é possível compreender com toda precisão como uma vítima experimentou na pele um certo ato de barbárie, esse processo imaginativo deve buscar explorar não a suposta realidade do horror de um ato bárbaro, mas sim as possíveis condições de humanidade que tendem a ser fragilizadas, interrompidas ou esmagadas por esse ato.

Essa proposta de Kertész tende a ficar mais clara se pensarmos que seu ensaio tem por base uma crítica negativa ao filme A lista de Schindler (1993), do cineasta norte-americano Steven Spielberg, e, em contrapartida, uma crítica positiva ao filme A vida é bela (1997), do cineasta italiano Roberto Benigni.

Em poucas palavras, Kertész condena A lista de Schindler por entender que esse filme se propõe a representar uma experiência supostamente autêntica dos horrores do Holocausto: sua narrativa se dedica a colocar o espectador em uma posição a partir da qual ele é supostamente capaz de vivenciar a realidade dos atos de violência perpetrados nos guetos e nos campos de concentração como se ele fosse mais uma vítima desses atos e, assim, como se ele fosse mais uma testemunha em primeira mão dos seus horrores. O problema dessa estratégia narrativa de Spielberg, Kertész parece sugerir, é o fato de que ela acaba por gerar uma espécie de efeito de verdade e, com isso, uma espécie de efeito de autoridade sobre fatos cuja barbaridade não é nem mesmo apreensível para aqueles que realmente os viveram. Em termos mais técnicos, para Kertész, toda tentativa de representar com fidedignidade um determinado evento bárbaro é naturalmente um processo de essencialização e violência ética, um processo no qual a realidade do trauma de uma vítima é subjugado às perspectivas e remodelado pelas opiniões e interesses daqueles que, ironicamente, tinham se disposto, antes, a tentar compreender as origens e as características desse trauma.

Com efeito, ao examinar essa prática, totalmente irresponsável, que pessoas alheias às experiências da barbárie têm de tentar explicá-las e representá-las em suas essências, Kertész comenta:

O sobrevivente é ensinado sobre como ele deve pensar a respeito do que ele experimentou, independentemente do quanto esse "pensar a respeito" condiz com suas experiências reais. A testemunha autêntica é ou logo será percebida como algo que está no caminho, e terá que ser empurrada de lado como o obstáculo que ela é. As palavras de [Jean] Améry carregam uma grande verdade: "Nós, as vítimas, vamos parecer pessoas realmente incorrigíveis e irreconciliáveis, vamos parecer os reacionários anti-históricos no sentido literal da palavra, e, no fim, o fato de que algum de nós tenha sobrevivido parecerá um contratempo técnico (KERTÉsZ, 2001, p. 268-269, tradução e ênfase nossas). 
Ainda a respeito de $A$ lista de Schindler, Kertész afirma que esse filme também falha ao negligenciar a dimensão da cultura na sua narrativa: Spielberg se mostra tão preocupado em representar com fidedignidade os horrores dos guetos e dos campos de concentração, que ele acaba por relegar a segundo plano aquilo que, na verdade, deveria ser sua análise de primeiro plano - a saber, precisamente as possíveis condições de humanidade, as possíveis relações de civilidade, que tendem a ser fragilizadas, interrompidas e esmagadas por atos de barbárie como os guetos e os campos de concentração. Para Kertész, em outras palavras, é fundamental que uma obra de arte sobre o Holocausto não trate essa barbárie como uma espécie de evento sobrenatural, como uma espécie de anomalia totalmente removida da existência humana; para ele, é fundamental que toda obra de arte sobre o Holocausto explique em que medida essa é uma barbárie que se originou nas entranhas da dimensão da cultura, isto é, em que medida diversas relações de humanidade e civilidade foram cessadas por atos de violência sistemáticos nascidos no seio delas mesmas. No entanto, para Kertész, por mais que todas as obras de arte sobre o Holocausto devam reiterar essa consanguinidade entre as dimensões da cultura e da barbárie, elas também devem reiterar uma defesa à dimensão da cultura, à dimensão da civilidade: uma obra de arte sobre o Holocausto não deve tratar de coroar os horrores e os traumas da barbárie, como Spielberg com frequência faz em A lista de Schindler, mas sim de enfatizar que, embora uma dimensão da barbárie possa vir a aflorar de dentro de uma dimensão da cultura, os laços de humanidade e de civilidade que predominam nessa dimensão devem, por fim, prevalecer - algo fundamental não apenas para que a cultura persista como uma forma de predisposição ao progresso, como uma forma de coragem à superação, mas também para que ela persista como um lugar de redenção social.

Essa é justamente a estética que Kertész parece encontrar em $A$ vida é bela, filme que, para ele, não se propõe a representar uma experiência supostamente autêntica dos horrores do Holocausto, mas que se propõe, antes, a criar uma experiência terna e valorosa na qual a sordidez e a atrocidade do Holocausto são sistematicamente subjugadas à resistência da dimensão da cultura - simbolizada, no enredo, no jogo de faz-de-conta proposto pelo protagonista a seu filho pequeno. A vantagem dessa estratégia narrativa de Benigni, Kertész parece sugerir, é o fato de que ela logra em criar uma espécie de efeito de conto de fadas e, com isso, uma espécie de efeito de coragem e aprendizado sobre fatos cuja barbárie, por mais absurda que seja, é um mal que pode e enfim tende a existir ali, por baixo, por entre, por trás e ao redor de toda a beleza da vida. Em termos mais técnicos, então, a estratégia de Benigni em ficcionalizar novos limites para a beleza da vida sem qualquer intenção de representar a realidade e a desgraça materiais das vítimas é bem-sucedida ao oferecer eventos que são espiritualmente mais verdadeiros do que qualquer fato histórico. No seu ensaio, ao examinar mais de perto A vida é bela, Kertész observa o seguinte a respeito da vida dos protagonistas nos campos de concentração: 
À primeira vista, esse conto de fadas parece bastante estranho no papel. Guido engana Giosue, seu filho de quatro anos, a acreditar que Auschwitz é só um jogo. Os participantes desse jogo recebem pontos à medida em que superam com sucesso certas dificuldades, e o vencedor irá ganhar um "tanque de verdade". Mas esse artifício do "jogo" não corresponde ele de maneira essencial à realidade de Auschwitz? Alguém poderia sentir o fedor de carne humana sendo queimada, e ainda assim se recusaria a acreditar que tudo isso podia ser verdade. Alguém poderia preferir encontrar alguma crença que o motivasse a sobreviver, e um "tanque real", para uma criança, é precisamente esse tipo de promessa sedutora (KerTész, 2001, p. 271, tradução e ênfase nossas).

E Kertész conclui mais adiante:

Nós agora entendemos que, em algum outro lugar, o "jogo" seria chamado civilização, humanidade, liberdade - tudo aquilo que os humanos consideravam como valioso. E quando o garoto, reunido com sua mãe e suspenso em seus braços grita "Nós vencemos!", suas palavras vêm a lembrar, pelo poder desse momento, uma elegia perpassada por pesar (KERTÉsZ, 2001, p. 272, tradução nossa).

Vê-se, então, que um dos principais interesses de Kertész em $A$ vida é bela está na capacidade que esse filme parece ter de reconhecer e enfatizar a resiliência e mesmo a impossibilidade de apreensão total da dignidade humana, processo de encorajamento, de elevação espiritual, que tende a ser desmerecido em A lista de Schindler, filme cuja narrativa se dedica em grande medida a representar a degradação e a subsunção sistemática da dignidade humana às depravações da barbárie. Claro, em nenhum momento Kertész - e isso vale para o meu próprio discurso aqui - sugere que a dimensão da barbárie e que o absurdo criativo das práticas de violência devem ser ignorados; ao contrário, é fundamental que essa dimensão e sua criatividade absurda para o mal sejam denunciadas, mas não de maneira a se tentar definir e representar essas violências em suas supostas realidades para as vítimas - algo que, como vimos, é impossível e até cruelmente irresponsável -, e sim de maneira a reiterar que elas são algo terrivelmente mundano, algo que tende a se originar por entre a ordem dos dias da dignidade humana, por mais que essa dignidade seja ela mesma também imprevisível e, portanto, felizmente indefinível em toda a sua extensão criativa.

Com efeito, creio que foi justamente a sugestão de tal lógica o que me fez lembrar desse ensaio de Imre Kertész durante a conversa que tive com Dina e Abdul: eu não sei como era Aleppo antes dos bombardeios, numa época talvez alegremente ordinária em que Dina ainda podia ser professora de biologia e Abdul ainda podia ser engenheiro químico; eu não sei como é Aleppo hoje, sem Dina como professora de biologia e Abdul como engenheiro químico; eu não sei nem mesmo o que Dina tinha em mente a primeira vez em que ela me respondeu que 
era de "Aleppo."; não sei o que há por detrás da risada incidental deles dois diante da desgraça que essa palavra parece representar e não sei que narrativas vieram à mente de Dina quando ela confirmou, com nova resignação, que eles vinham, sim, de "Aleppo".

No entanto, eu sei que eles - ainda - têm um interesse legítimo em saber como vão meus estudos, pois com essa conversa eles parecem ter uma chance de se reaproximar daquela dimensão da cultura à qual pertenciam e, de outro modo, à qual ainda pertencem; sei que eles têm um interesse legítimo em saber como é a minha vida em Portugal, pois seus filhos também vivem, estudam e trabalham neste país; sei que eles esperam me ver aos sábados, pois de alguma forma eu devo representar para eles uma ordem dos dias, um sinal de que tudo ainda vai bem.

Em outras palavras, creio, enfim, que a conversa que tive com Dina e Abdul fez com que eu me lembrasse do ensaio de Imre Kertész porque na convicção de Guido de que a vida há de ser bela estão também as convicções de Dina e Abdul; porque na abdicação de Guido de si mesmo para que seu filho tenha uma vida íntegra está a abdicação de Dina e Abdul de si mesmos para que seus filhos tenham uma vida íntegra; porque nas risadas de Guido e de seus colegas diante dos absurdos de uma barbárie inefável estão as risadas de Dina e Abdul diante dos absurdos de uma barbárie que, embora outra, é também inefável; porque, enfim, na luta de Guido por proteger, criar e espalhar a dignidade que faz humanos a ele e a seu filho está a luta de Dina e Abdul por proteger, criar e espalhar a dignidade que faz humanos a eles e a seus filhos.

Não é preciso ler muito a fundo teorias e manuais técnicos sobre os direitos humanos para perceber que uma de suas premissas centrais, senão a sua premissa central, é a preservação da dignidade humana de modo irrestrito - isto é, individual ou coletivamente, e sem qualquer distinção com fins de privilégio daquilo que define eticamente as pessoas, como suas origens, etnias, gêneros, corpos, credos, classes sociais, orientações sexuais etc.

Já no Preâmbulo da Declaração Universal dos Direitos Humanos, por exemplo, é possível ler que reconhecer a dignidade como inerente às pessoas e defender essa proposição é um objetivo e base para o exercício dos direitos humanos; o Título Um da Carta dos Direitos Fundamentais da União Europeia é inteiro dedicado a estabelecer a defesa da dignidade humana como objetivo e base para o exercício desses Direitos Fundamentais; as primeiras páginas do Relatório Final da Comissão Nacional da Verdade propõem que dentre os objetivos dessa pesquisa está reclamar a dignidade do país e denunciar de que maneira os interesses do Governo Militar (1964-85) no Brasil foram executados, deliberadamente ou não, em detrimento da dignidade humana (Brasıl, 2014, p. 21 e p. 200); a Agenda 2030 da Organização das Nações Unidas para o desenvolvimento sustentável tem como um dos principais objetivos práticos a defesa de um trabalho digno a todos como meio ao crescimento econômico generalizado (Assembleia Geral, 2016, p. 16); Boaventura de Sousa Santos, ao conceituar sua ideia de pensamento abissal denuncia o fato de 
que, embora os humanistas europeus dos séculos XV e XVI colocassem a dignidade humana como base para a concepção de humanidade, eles também consideravam que povos indígenas eram na verdade povos sub-humanos, de modo que eles não eram realmente dignos a usufruir de alguma dignidade (SANTOS, 2010, p. 33). Exemplos que indiquem a dignidade como cerne para a concepção e para o exercício dos direitos humanos, como vemos, realmente não faltam; no entanto, quanto mais lemos a respeito dos direitos humanos e, assim, mais nos aprofundamos na ideia de dignidade humana, mais nos damos conta de que, por fim, não há realmente uma definição, precisa e incontroversa, para o conceito ou sentido de dignidade. Para a Declaração Universal dos Direitos Humanos e para a Carta dos Direitos Fundamentais da União Europeia, por exemplo, a ideia de dignidade humana parece consistir essencialmente em uma plenitude da igualdade e equidade sociais, assistidas e garantidas por uma justiça distributiva; para o Relatório Final da Comissão Nacional da Verdade, a ideia de dignidade por vezes se associa à tentativa de retificar, diante do cenário internacional e para a própria população brasileira, os atos de violência perpetrados pelas autoridades militares, enquanto por vezes essa ideia parece, de fato, se associar a uma espécie de garantia de bem-estar à população brasileira em toda a sua heterogeneidade; na Agenda de zozo da ONU, a ideia de dignidade é proposta sob um tom mais conformista e basicamente designa o esforço coletivo para se garantir ao máximo de pessoas possível condições não exploratórias de se viver, em particular de se trabalhar; no pensamento abissal de Sousa Santos, a dignidade é sobretudo a hipótese de todas as pessoas viverem sem o prejuízo de terem suas existências essencializadas e assim degeneradas e exploradas por alguma espécie de pensamento hegemônico.

Mas, e com relação às artes?

Isto é, de que maneira a literatura e a crítica literária, como é o nosso caso, podem pressupor a dignidade humana de modo a que ela opere como uma espécie de orientação epistemológica o mais inclusiva possível e, assim, nos permita contribuir para um melhor exercício dos direitos humanos?

No Prefácio de O Renascimento: estudos sobre arte e poesia $(1873 / 1980),{ }^{2}$ Walter Pater (1839-1894), um defensor da arte como método de formação humanista, sugere que uma vez que é impossível definir o belo em um sentido abstrato, o valor de se tentar defini-lo está, por fim, em tudo aquilo que é proposto ao longo do caminho (PATER, 1873198o, p. xix) - isto é, uma vez que não é possível definir o belo em um sentido abstrato, o valor das tentativas de defini-lo está no fato de que elas acabam por verificar que o belo, na verdade, está em muitos lugares e expresso de muitas maneiras diferentes, de modo que a verdadeira relevância da crítica de arte está na sua habilidade de procurar e encontrar o belo, bem como, por extensão, na sua habilidade de sensibilizar as pessoas para tudo aquilo que pode vir a ser belo. A meu ver, o mesmo pode ser dito da relação entre dignidade, literatura e crítica literária à luz dos direitos humanos: uma vez que não é possível definir a

2 No original, The Renaissance: studies in art and poetry. (ver PATER, 1980) 
dignidade em um sentido abstrato, o valor das tentativas de defini-la está no fato de que elas acabam por verificar que a dignidade, na verdade, está em muitos lugares e expressa de muitas maneiras diferentes, de modo que a verdadeira relevância da literatura e da crítica literária está na suas habilidades de procurar e encontrar a dignidade, bem como, por extensão, nas suas habilidades de sensibilizar as pessoas para tudo aquilo que pode vir a ser uma dimensão, uma natureza, uma expressão da dignidade.

É de acordo com essa hipótese que irei discutir, na seção seguinte, o livro $O$ que os cegos estão sonhando? da escritora e professora paulistana Noemi Jaffe.

\section{Discussão: a voz da dignidade em $O$ que os cegos estão sonhando? de Noemi Jaffe}

O livro $O$ que os cegos estão sonhando? (2016) de Noemi Jaffe não é bem um livro e tampouco foi propriamente escrito por ela; grande parte desse volume é, na verdade, um diário de guerra escrito por sua mãe, Lili Jaffe, nascida Lili Stern na cidade de Szenta, na Sérvia, e prisioneira em Auschwitz e Bergen-Belsen entre 1944 e 1945 - cerca de um ano antes do fim da Segunda Guerra Mundial (1939-45), portanto.

Mas o diário de guerra de Lili Jaffe, embora de fato compile suas memórias sobre os dias nos campos de concentração, também não é propriamente um diário de guerra, não no sentido literal; escrito na segurança da Suécia, já após a libertação dos prisioneiros da Solução Final, esse diário é a narração em tempo presente de narrativas passadas, de modo que o que está anotado ali não são registros testemunhais propriamente ditos, mas antes testemunhos reimaginados, testemunhos retrabalhados, recapitulações um tanto impressionistas dos horrores e dos traumas (mas também das esperanças) vividos em meio à violência dos campos de concentração.

Essas impressões são evidentes em, por exemplo, três momentos fundamentais das memórias de Lili Jaffe: no primeiro registro do diário, quando ela relembra seu medo e apreensão diante do desalojamento de sua família; no primeiro registro após a morte de Adolf Hitler (1889-1945), quando ela relembra seu amargo sentimento de vitória; e no último registro do diário, quando ela por fim relembra a tranquilidade e até mesmo um certo ócio permitidos por novos tempos de paz:

Szenta, 25 de abril de 1944

Todos à minha volta, assim como eu, estamos tristes. Sabemos o que está acontecendo e também o que acontecerá. Meu pai está sentado no sofá, durante a manhã toda, calado, fitando o nada. Por vezes, olha-nos e fecha os olhos tristes. Minha mãe nos consola: não acredita no mal, porém está arrumando as malas, faz doces e suspira fundo, sem que ninguém possa ver.

Meu irmão e eu observávamos e, sendo duas crianças, saímos para chorar. 
Ninguém nos conta nada, mas sabemos o que está acontecendo. Sabíamos que no dia seguinte, às oito horas, os alemães viriam nos buscar e nos arrancar de nosso lar (JAFFE, 2016, p. 15).

Padborg, 10 de maio [de 1945]

Atravessamos a fronteira alemã. Estamos na Dinamarca. O alemão saltou do trem e grita:

- Hitler morreu! O trabalho está concluído.

Enfermeiras dinamarquesas, com uniformes brancos da Cruz Vermelha, vêm nos retirar dos vagões. Oferecem doces. Nem olhamos mais para esses pães negros e secos. Atiram-nos flores e nos levam de carro, cinquenta por vez. Chegamos a uma propriedade rural. Discursaram para nós. Que não nos aborreçamos por ter de dormir, esta noite, sobre palha. Que levemos em conta que estamos sujas. Ganhamos excelentes cobertores ingleses. Como já estava escuro, não ganhamos comida. Deitamos (JAFFE, 2016, p. 38).

[Zagreb,] 30 de setembro de 1945

É o aniversário de Hajnal e o comemoramos juntamente com a volta à casa, porque apenas hoje conseguimos arrumar nosso novo lar. Até agora dormimos no chão, sobre os tapetes e já temos belos móveis, cada um com a sua cama.

Não vimos praticamente nada da cidade, além desta rua e da Vlaška, que fica ao lado da nossa e vamos ali fazer compras. Estivemos muito ocupados, mas, de agora em diante, teremos mais tempo (JAFFE, 2016, p. 81).

Providencio aqui essas três entradas no diário de Lili Jaffe porque elas com efeito indicam os três grandes segmentos temáticos em que sua narrativa se divide: os dias nos campos de concentração, em que sua dignidade é sistematicamente fragilizada; os dias de transição dos campos para as zonas de segurança, em que ela se reabitua às muitas ideias de dignidade; e os primeiros dias do pós-guerra, em que as muitas facetas da dignidade já começam a se confundir, felizmente, com a trivialidade dos dias.

No artigo "Uma questão de narração: a voz na lei internacional dos direitos humanos", ${ }^{3}$ Joseph Slaughter, ainda hoje um dos estudiosos mais influentes sobre as relações entre literatura, crítica literária e direitos humanos, sugere que, de um ponto de vista jurídico, uma característica do Bildungsroman - o romance de formação no qual ele é especialista - é sugerir que restrições impostas à "liberdade, propriedade, segurança e resistência à opressão" (itens da Declaração dos Direitos do Homem e do Cidadão de 1789) limitam a habilidade de um indivíduo de se manter "fixo" (Slaughter, 1997, p. 413). E, segundo ele, "[em] acordo com a subjetividade refletida nas normas dos direitos humanos internacionais, a fixidez do herói moderno depende da sua habilidade de contar a sua própria história" (Slaughter, 1997, p. 413). A partir dessa lógica, Slaughter chega à sua conclusão

3 No original, "A question of narration: the voice in international human rights law". (ver SLAUGHTER, 1997) 
sumária - a saber, a de que os abusos contra os direitos humanos em geral se caracterizam por um impedimento da liberdade que o sujeito moderno deveria ter para narrar sua própria história. Essa lógica claramente remonta à minha discussão da seção anterior: por um lado, Imre Kertész denuncia o fato de que certos estudos e certas obras de arte, ainda que de maneira bem-intencionada, acabam por se apropriar da capacidade que as vítimas de certos traumas deveriam ter de narrá-los, algo que tende a se caracterizar como uma violência ética; por outro lado, na beneficamente instável ideia de dignidade parece estar sugerida a hipótese de que uma vida digna é aquela em que o sujeito tem a liberdade e o acesso às condições necessárias para usufruir daquilo que ele efetivamente deseja ter como parte integrante da sua história, da sua formação, das suas experiências. Esses três relatos de Lili Jaffe já nos dão alguma prova disso.

No primeiro relato, nós acompanhamos uma narrativa de resignação: cientes do triste fim anunciado, mas presos sob a legalidade das ordens de evacuação emitidas pelo Estado Nazista, a protagonista e sua família se veem coagidas a abrir mão de suas próprias existências - existências ordinárias, típicas do ambiente doméstico, mecanizadas que sejam na regra dos dias - para cumprir com as imposições emitidas por esse Estado. No segundo relato, nós acompanhamos uma narrativa de recuperação: pelo comportamento da protagonista e pelas condições materiais em que ela se encontra - física e psicologicamente fragilizada, subsistindo como um elemento numerado, mas despersonalizado em meio a uma horda de prisioneiras, vivendo os dias à base de pão velho -, logo notamos que ela se encontra padecida de uma privação sistemática de si mesma - por um lado, uma falta de higiene, saúde e boa alimentação, enquanto, por outro, uma constante submissão a explorações do seu corpo e da sua mente. Ao mesmo tempo, diante da notícia da morte de Hitler, ela e as demais prisioneiras logo se veem livres para usufruir de um mínimo de condições de vida melhores - o acesso a doces, a cobertores e, embora ela não narre isto de fato, mas seja possível subentender, também uma maior liberdade de ir e vir, uma maior liberdade para se fazer o que se bem entender. No terceiro relato, nós acompanhamos uma narrativa de redenção: por mais que as destruições sistemáticas da guerra tenham privado a protagonista de materializar os planos e rumos da sua antiga vida, nós a acompanhamos em meio a um recomeço, em meio a uma nova vida na qual mesmo os elementos mais ordinários - tapetes, móveis, camas individuais, o acesso às compras, a possibilidade de se celebrar o aniversário de alguém - se tornam evidências de uma liberdade narrativa, isto é, de uma liberdade que a protagonista passa a ter de narrar a sua própria história, por mais prosaica que ela seja.

No primeiro relato, nós acompanhamos, portanto, o prenúncio do que insinuei como uma interrupção ou uma despossessão da dignidade: na medida em que têm de se submeter às ordens do Estado Nazista e esperar pelo desalojamento, a protagonista e sua família são sistematicamente impedidos de dar continuidade às suas próprias narrativas - no lugar delas, o que temos, com efeito, é a dominância de narrativas que, embora contingentes, tendem a ter que respeitar uma nova lógica 
criativa: a saber, a da sobrevivência enquanto busca por não morrer. No segundo relato, nós acompanhamos, então, uma transição, uma espécie de reconquista ou reaquisição da dignidade: tendo atrás de si os campos de concentração e diante de si uma nova legitimação política permitida pela morte de Hitler, a protagonista e suas companheiras se veem em uma nova posição na ou a partir da qual elas são capazes de produzir suas próprias narrativas, ainda que qualquer uma dessas produções tenha, necessariamente, de respeitar uma segunda lógica criativa: a saber, a sobrevivência enquanto nova oportunidade por não se ter morrido. No terceiro relato, nós acompanhamos, por fim, uma conclusão, uma espécie de sedimentação ou consumação da dignidade: na medida em que têm diante de si uma espécie de página em branco, uma oportunidade de recomeçar o planejamento de uma nova narrativa, a protagonista e suas companheiras se veem livres para produzir suas narrativas segundo as evoluções do tempo corrente, ainda que cada uma dessas produções tenha de respeitar, necessariamente, uma terceira lógica criativa: a sobrevivência enquanto liberdade criativa para se viver e narrar não se tendo morrido.

Ao longo da narrativa de Lili Jaffe, ela nos deixa claro que uma estratégia que encontrou para sobreviver em Auschwitz foi burlar a fiscalização de uma oficial responsável pelo seu grupo a fim de ser selecionada para trabalhar na cozinha junto com suas primas - um trabalho pesado, mas no qual o acesso à alimentação e a uma certa estabilidade de rotina eram mais assegurados (JAFFE, 2016, p. 20-21). Ela comenta a respeito dessa nova etapa no campo de concentração:

Auschwitz, 6 de julho (?) de 1944

Já faz dois dias que estou na cozinha. É difícil. Acordar às três e logo ir para o trabalho. Descascar batatas, repolho, cenoura, quase sempre até às doze e trinta ou até terminar. Ontem acabou sendo horrível. Tivemos de descascar trezentos quilos de batata, duzentos quilos de repolho. Terminamos às seis da tarde. Mas durante o dia todo tínhamos de descarregar um caminhão e levar tudo para o depósito. Saco de farinha de cento e cinquenta quilos para duas levarem, outro tanto de açúcar. O mais difícil eram os fardos de papel, cinquenta quilos para cada uma. Depois, pão. Fazíamos então uma corrente humana e jogávamos os pães de mão em mão. Ao terminar, estávamos arrebentadas. O pior de tudo era saber que não conseguiríamos terminar de limpar tudo. Mas éramos obrigadas a fazer isso. Passamos à noite e varamos até às onze horas do dia seguinte. Já nem conseguia levantar as mãos. Estava cansada e com sono. Às onze horas, fomos para o pavilhão. Era de ouro, comparado aos demais. Tínhamos cobertores - dois para cada uma de nós. E de lã. Nas camas, havia seis de nós. Fantástico. Café adoçado. Comida, o quanto aguentássemos. Estávamos satisfeitas. Mas o trabalho era muito duro (JAFFE, 2016, p. 22).

Enfatizo aqui essa entrada no diário de Lili Jaffe por causa do terrível contraste que ela acaba por estabelecer com a primeira entrada - a entrada na qual ela narra o comportamento da sua família enquanto esperam pelo desalojamento. Claro, ambos os relatos correspondem àquilo que me referi, à luz das teorias de Slaughter, 
como um total impedimento de se tecer uma narrativa própria; no entanto, as formas de resignação são bastante distintas. Enquanto, no primeiro relato, a resignação consiste ainda em um medo, dor e tristeza por se ter de abrir mão da realidade e da liberdade correntes - as quais incluem, por suposto, a liberdade de se narrar a própria realidade -, no segundo relato, a resignação se confunde com a submissão forçada, com a escravização sistemática, uma nova realidade na qual liberdades não existem efetivamente, uma nova realidade na qual a possibilidade de uma narrativa própria é totalmente substituída pela obrigatoriedade, sob pena de morte, de se construir a narrativa de outrem - em particular uma narrativa na qual os despossuídos e despersonalizados são forçados a narrar para si mesmos e a seus próximos os eventos da sua própria destruição, do seu próprio e incontrolável fim. É curioso notar, porém, como no segundo relato - o relato do dia 6 de julho de 1944 - a narrativa de Lili Jaffe consegue, com muita discrição, tornar a tomar conta de si mesma, uma humilde reconquista que enfim se confunde com uma delicada possibilidade de dignidade: o súbito acesso a um dormitório um pouco melhor, com camas e cobertores um pouco melhores, bem como a possibilidade de se colocar açúcar no café ou de se comer sem grandes restrições, se expressa como uma narrativa um tanto mais livre por parte da protagonista, uma narrativa na qual as suas condições para dormir e para se alimentar não são diretamente reguladas por algum oficial dos campos de concentração. Claro, não pretendo de modo algum atenuar a violência à qual as personagens estiveram sujeitas; ao contrário, é fundamental notar como na narrativa de Lili Jaffe, em uma convergência sutil com a narrativa de Roberto Benigni, toda a dimensão da civilidade - e, portanto, também da dignidade - acaba por se resumir à alegria de um cobertor melhor e uma colher de açúcar.

Uma outra característica bastante notável do livro de Noemi Jaffe é a pequena antologia de textos pessoais editada logo após o diário de sua mãe; designados por títulos simples como "Destino", "Frio", "Fome", "Medo" ou "Memória" - palavras em geral retiradas das próprias narrativas examinadas - , os textos de Noemi Jaffe são breves ensaios pessoais, breves impressões e perguntas estimuladas pelos testemunhos de sua mãe, sejam eles relatos extraídos do diário, sejam eles relatos transmitidos verbalmente. Um desses ensaios tem justamente o título "Dignidade”. Noemi Jaffe se interessa pelo seguinte comentário de sua mãe, uma simples sequência de eventos ocorridos provavelmente em janeiro de 1945:

Numa noite, precisamos dormir no meio da serragem. Eu sabia que tinha muitos piolhos, por isso me despi, dobrei minhas roupas e dormi nua. Assim, os piolhos não iriam infestar a minha roupa (JAFFE, 2016, p. 108).

A pergunta que vem à mente de Noemi Jaffe diante desse relato é bastante curiosa; ela se pergunta: "Será que o sentido de dignidade ajuda a sobreviver?" (JAFFE, 2016, p. 108). Digo que essa é uma pergunta curiosa não apenas pela relação clara que ela estabelece com a ideia de dignidade nesse excerto - a preservação da vida por meio do asseio e da saúde do corpo -, mas também pela maneira como 
Noemi Jaffe coloca a questão: "Será que o sentido de dignidade ajuda a sobreviver?" Ela continua após se propor essa pergunta:

Primo Levi fala dos muçulmanos, aqueles judeus que andavam tão curvados, inertes e apáticos, que acabaram recebendo este apelido por causa de sua postura, semelhante à da reza muçulmana. Diz que os muçulmanos eram os primeiros a morrer; aqueles para quem nada mais fazia sentido. Nem levantar minimamente a cabeça, nem curar as feridas. Mas quem era capaz de manter a dignidade? Por que alguns mantinham mais que outros? (JAFFE, 2016, p. 108).

E, mais adiante, ela acrescenta:

O dicionário etimológico diz que dignidade vem de merecimento, como no caso de "ser digno de". Se é mesmo assim, esta dignidade que hoje se compreende como um sentido de autoestima, de orgulho da própria personalidade e de manutenção de uma certa hombridade, tem origem, na verdade, em uma mera demonstração de que um indivíduo inferior é capaz de fazer jus à sua posição inferior; ele a merece (JAFFE, 2016, p. 109).

Claramente, nesse breve ensaio, Noemi Jaffe nos fornece ainda outra definição para dignidade, uma definição que não corresponde muito bem a essa espécie de lógica ou procedimento de identificação da dignidade que venho trabalhando aqui. No entanto, havemos de lembrar, como sugeri há pouco, que o valor das tentativas de se definir a dignidade está no fato de que essas tentativas acabam por verificar que a dignidade, na verdade, está em muitos lugares e expressa de maneiras diferentes, de modo que uma relevância da literatura e da crítica literária para os direitos humanos está na suas habilidades de procurar e encontrar a dignidade, bem como, por extensão, nas suas habilidades de sensibilizar as pessoas para tudo aquilo que pode vir a ser uma dimensão, natureza ou expressão da dignidade.

Com efeito, a meu ver, o que Noemi Jaffe propõe nesse breve ensaio é menos um sentido ou uma definição para dignidade do que uma de suas dimensões - a saber, a dimensão da integridade, em particular, no caso, a integridade física. Se, como vimos, uma das maneiras de se verificar uma espécie de bem-estar dos direitos humanos é verificar em que medida um indivíduo ou um grupo de indivíduos tem liberdade e condições para narrar sua própria história, parece natural pressupor que nessas histórias constem ou possam constar também narrativas sobre um domínio do próprio corpo: um domínio sobre a dor, o sofrimento, a higiene, a sexualidade, a reprodução, a aparência, a deficiência etc.

É claro que por si só a integridade física já se define como uma dimensão da dignidade humana, mas é importante enfatizar que um grande estímulo para se contribuir para uma preservação da integridade física é o fato de que a sua fragilização raramente vem desassociada de uma fragilização também da integridade psicológica e emocional. 
Um dos momentos mais tensos da narrativa de Lili Jaffe é aquele em que ela assume a culpa por ter contrabandeado um pouco de margarina para fora da cozinha; no dia 2 de agosto de 1944, a fim de evitar que suas companheiras sejam punidas pelo contrabando, Lili Jaffe se entrega a dois oficiais alemães para o castigo.

Esse castigo se dá da seguinte forma:

Enquanto isso, ele me conduziu para fora, até um monte de tijolos, onde ordenou que me ajoelhasse. E que eu segurasse um tijolo enorme por cima da cabeça, um tijolo que eu mal conseguia erguer. Apanhei o tijolo, mas logo precisei colocar de volta, porque não conseguia erguê-lo.

O alemão via como eu estava sofrendo. E disse:

- Olhe: se você não fizer força, ela [a outra oficial] voltará. E aí, sabe o que espera por você?

Levantei o tijolo até a altura da cabeça, com um esforço enorme, mas não consegui segurar. Caiu-me sobre a cabeça. Pensei que desmaiaria. Mas fui forte. Tive a visão de que todos estavam passando pela revista, minhas primas inclusive. Lágrimas caíam de meus olhos feito chuva, não porque eu estivesse arrependida do que fiz, mas de dor mesmo. Fiquei ali, de joelhos, por duas horas. Aí apareceu o alemão e disse:

- Levante-se! Entre na cozinha e continue trabalhando!

Depus o tijolo e tentei levantar. Aquele lugar duro em que fiquei ajoelhada me machucou tanto os joelhos que caí. Ouvi novamente a voz do alemão. Quis levantar, mas não consegui. Fiquei sentada uns dez minutos. Depois voltei para a cozinha, onde desmaiei. Minhas primas choravam; punham compressas frias em mim; consolaram-me, até eu melhorar (JAFFE, 2016, p. 24-25).

Essa narrativa de Lili Jaffe é particularmente significativa para a lógica que estamos trabalhando porque ela mostra com clareza como a banalidade do mal, uma vez legitimada, tem o poder de se apropriar de toda construção narrativa dos indivíduos oprimidos por essa legitimidade. Em alguns momentos após esse episódio de tortura, Lili Jaffe parece sugerir que esteve à beira da desistência e da morte justamente por conta das suas feridas nas pernas - isto é, caso ela tivesse desistido e sido morta, isso muito provavelmente teria sido facilitado por seus machucados; mas esses machucados só existem porque ela foi torturada pelas autoridades nazistas; mas ela foi torturada porque tentou contrabandear margarina para companheiras que não tinham mais forças para os trabalhos forçados; mas tais trabalhos forçados só existiam em primeiro lugar por causa da legalidade da Solução Final. Ou seja: em grande medida, a Solução Final e sua legalidade não apenas abreviaram e exterminaram vidas, mas fizeram isso por meio de um sequestro das narrativas individuais, um sequestro que tinha por fim não apenas despossuir os indivíduos das suas liberdades e condições de tecer suas próprias narrativas, mas também de tomar para si a autoridade de tecer tais narrativas da maneira mais sórdida e insultante possível. 


\section{Conclusão: outro breve excurso sobre a dignidade humana}

Embora a maior parte do diário de Lili Jaffe retrate as violências absurdas de Auschwitz e Bergen-Belsen, bem como o sentimento amargo de vitória diante dos processos de libertação e reinserção social, os seus relatos, por incrível que pareça, se encerram com os primeiros dias de uma história de amor - se encerram, em outras palavras, com uma reconquista da dimensão da cultura, uma dimensão na qual a dignidade tende a ser mais acessível na medida em que as liberdades $e$ condições para se narrar uma história própria tendem a ser mais vigentes.

Por um lado, é fundamental notar como o acesso a diferentes formas materiais de bem-estar passa a predominar na narrativa de Lili Jaffe; em uma das entradas acima, já vimos como o primeiro sinal de liberdade se materializa, para ela e suas companheiras, no ato de descartar os restos de pão velho que tinham enrolados nas roupas e receber os doces distribuídos pelos funcionários da Cruz Vermelha, e essa lógica passa a consistir em normalidade de vida nos relatos após maio de 1945:

Copenhagen, 5 de março [de 1945]

Chegamos às oito da manhã em Copenhagen. O trem parou diante do Porto. Já nos aguardava um navio enorme de três andares. Quando saímos do trem, cada pessoa recebeu um litro de iogurte, que bebemos imediatamente, e doces. Depois, para o refeitório. No navio, entravam cinquenta por vez. Sentamos quatro em cada mesa. Vieram garçons com cardápio. - O que desejam?

Não conseguíamos achar as palavras. A enfermeira percebeu isso e fez o pedido por nós (JAFFE, 2016, p. 40).

Por outro lado, é fundamental perceber nos relatos de Lili Jaffe uma progressiva liberdade narrativa, isto é, uma capacidade de sugerir narrativas que não sejam mais narrativas normalizadas pelos limites da Solução Final, mas sim narrativas cujas contingências se confundem com as liberdades dos seus sujeitos de projetálas e de materializá-las segundo seus próprios desejos de vida, segundo suas próprias concepções do que faz ou faria de uma vida uma vida digna. Se no excerto acima acompanhamos Lili Jaffe em uma recuperação psicológica e emocional por meio de uma recuperação física, no excerto abaixo, escrito em um tom quase idílico, acompanhamos sua recuperação psicológica e emocional por meio de uma recuperação afetiva e erótica:

[Kommelnäs,] 28 de julho [de 1945]

Ontem, [Juro] pediu-me, depois do almoço, que saísse com ele para passear. Concordei. [...] Depois do jantar, saímos e continuamos o nosso passeio. Paramos no bosque e ficamos ouvindo os grilos; contemplamos as estrelas, a paisagem; estivemos mais tempo calados do que falando. Chegamos até um banco e sentamos. Tomou-me a mão, baixou a cabeça e, como se estivesse falando consigo próprio, em voz baixa, perguntoume: Lilika, diga-me com sinceridade, consegue sentir quanto a amo? [...] 
Sentia-me como se estivesse sendo sufocada por alguma coisa. Sentia tanto que, se soubesse dizer que gostava dele - mas tinha uma só palavra na ponta da língua -, diria que amo você, Juro. Mas eu não disse. Levantei-me e continuamos o passeio. Ele recomeçou. Faz tempo que sinto que a amo, permita-me que a tuteie. ${ }^{4}$ Quer? Sim, quero, para mim também será mais fácil. Amo você como jamais amei alguém antes [...]; sinto que você gosta de mim. Lili, quanto a amo, mas me diga com sinceridade o que você sente por mim, não deixe que eu me torture mais. Não sei o que eu disse. Beijou-me e eu corri dele e corria em torno do prédio. Perguntaram-me o que nos perturbou tanto e eu pedia para que não me perguntassem (JAFFE, 2016, p. 66).

É possível notar, portanto, como o formato do diário de Lili Jaffe cumpre com o que sugeri acima, à luz das teorias de Imre Kertész, Walter Pater e Joseph Slaughter, a respeito de uma espécie de procedimento para se reconhecer a dignidade em suas muitas dimensões - um procedimento particularmente válido para a crítica literária como prática solidária à prática dos direitos humanos. Uma vez que, embora narrados em tempo presente, os relatos de Lili Jaffe são memórias registradas retrospectivamente a partir de uma posição de segurança, eles são naturalmente evidências materiais de sua liberdade de narrar sua própria história - uma história que registra dentro de si mesma tanto uma restrição da sua habilidade de narrar, como são os dias nos campos de concentração, quanto uma soberania da sua habilidade de narrar, como são os dias nas zonas de recuperação. O conteúdo desses relatos nos permite perceber que não é salutar que tentemos definir ou conceituar a dignidade humana, pois corremos o risco de subjugar às nossas perspectivas pessoais a dignidade de outros - processo de violência ética que curiosamente parece ser indissociável da prática de se subjugar às nossas perspectivas pessoais a narrativa de outros. Uma provável evidência disso é o fato de que o Holocausto - a Solução Final, os desalojamentos, os guetos, os campos de concentração, a criatividade da sobrevivência contra a criatividade da violência - se apresenta para nós em grande medida como uma estética consagrada: por mais surpreendentes que eventualmente possam ser as obras de arte ou os relatos dos sobreviventes sobre esse extermínio, nós, vítimas extremamente distantes dessa sordidez, tendemos a apreendêlo como um grande objeto cultural, dotado de regras narrativas internas. No entanto, as narrativas de Lili Jaffe como consequência da sua sobrevivência - seus dias na Escandinávia, seus primeiros dias de uma relação amorosa, seu reencontro com seu irmão, seu retorno à Sérvia - se apresentam para nós como uma estética contingente: a partir do momento em que a protagonista embarca em uma jornada de construção ou reconstrução da sua própria história, todo o reino das possibilidades futuras se insinua para nós de maneira totalmente imprevisível - tão imprevisível, que por vezes ele nos parece uma grande ficção, um grande conto de fadas.

4 Neste caso, tuteie significa usar o pronome de tratamento tu, para relações informais. 


\section{Referências}

A Lista de Schindler. Direção de Steven Spielberg. Los Angeles: Universal Pictures, 1993. (195 min.)

Assembleia Geral das Nações Unidas. Agenda 2030 de Desenvolvimento Sustentável. Nova Iorque, EUA, 2016. Disponível em: https://www.instituto-camoes. pt/images/ods_2edicao_web_pages.pdf. Acesso em: 24 nov. 2019.

Assembleia Geral das Nações Unidas. Declaração Universal dos Direitos Humanos. Paris, França, 10 dez. 1948. Disponível em: https://www.ohchr.org/EN/UDHR/ Pages/Language.aspx?LangID=por. Acesso em: 24 nov. 2019.

A Vida é Bela. Direção de Roberto Benigni. Roma: Melampo Cinematografica. 1997 (112 min.)

Brasil. Comissão Nacional da Verdade. Relatório - volume 1. Brasília, 2014. Disponível em: http://cnv.memoriasreveladas.gov.br/images/pdf/relatorio/volume_ 1_digital.pdf. Acesso em 24 nov. 2019.

Conselho Europeu. Carta dos Direitos Fundamentais da União Europeia. Nice, França, 7 dez. 2ooo. Disponível em: https://eur-lex.europa.eu/legal-content/PT/ TXT/?uri=LEGISSUM\%3Al33501. Acesso em: 24 nov. 2019.

JAFFe, Noemi. O que os cegos estão sonhando?. Lisboa: Relógio D’Água, 2016.

Kertész, Imre. Who owns Auschwitz?. Tradução de John McKay. The Yale fournal of Criticism, Baltimore, v. 4, n. 1, p. 267-272, Primavera 2001. Disponível em: https: //muse.jhu.edu/article/36875. Acesso em: 10 nov. 2019.

PATER, Walter. The Renaissance: studies in art and poetry. Berkeley: University of California Press, 1873/1980.

Slaughter, Joseph. A question of narration: the voice in international human rights law. Human Rights Quarterly, Baltimore, v. 19, n. 2, p. 406-440, maio 1997. Disponível em: https://muse.jhu.edu/article/13578. Acesso em 10 nov. 2019.

SANTos, Boaventura Sousa. Para além do pensamento abissal: das linhas globais a uma ecologia de saberes. In: SAntos, Boaventura Sousa; Meneses, Maria Paula (orgs.) Epistemologias do Sul. São Paulo: Cortez, 2010.

Recebido em 24 de novembro de 2019

Aprovado em $1^{\circ}$ de março de 2020 


\section{Resumo/Abstract/Resumen}

\section{A voz da dignidade em $O$ que os cegos estão sonhando? de Noemi Jaffe}

\section{Fábio Waki}

Este artigo propõe uma leitura de $O$ que os cegos estão sonhando? (2014), de Noemi Jaffe, a fim de discutir como uma das principais responsabilidades da crítica literária, à luz da relação entre literatura e direitos humanos, é, para além de colaborar com a eficiência da elaboração e aplicação desses direitos, a de colaborar com uma explicitação de tudo o que pode consistir em uma dimensão da dignidade humana. Ciente de que dignidade é um conceito polêmico no contexto dos direitos humanos, proponho debater aqui menos como a literatura pode nos ajudar a definir o que é dignidade - uma perspectiva recorrente na crítica literária à luz dos direitos humanos -, e mais como ela pode contribuir com a ideia de que na impossibilidade de se definir dignidade há, enfim, uma boa premissa para se defender os direitos humanos.

Palavras-chave: direitos humanos; crítica literária engajada; Segunda Guerra Mundial; história e memória; empatia.

\section{The voice of dignity in Noemi Jaffe's $O$ que os cegos estão sonhando?}

\section{Fábio Waki}

This article examines Noemi Jaffe's $O$ que os cegos estão sonhando? (2014) in order to discuss how one of the main responsibilities of literary criticism, in the context of the relation between literature and Human Rights, is not just to contribute to the elaboration and application of these rights, but also to contribute to an account of all that might concern a dimension of human dignity. Aware that dignity is a controversial concept in the realm of Human Rights, I suggest to debate here, not so much how literature can help us define what dignity is - a common perspective in literary criticism in its connection to Human Rights -, but how it might contribute to the idea that the very impossibility of defining dignity might be a good premise to defend Human Rights in the first place.

Keywords: Human Rights; committed literary criticism; Second World War; history and memory; empathy.

\section{La voz de la dignidad en $O$ que os cegos estão sonhando? de Noemi Jaffe}

\section{Fábio Waki}

Este artículo propone una lectura de O que os cegos estão sonhando? (2014), de Noemi Jaffe, para que podamos discutir cómo una de las principales responsabilidades de la crítica literária, a la luz de la relación entre literatura y derechos humanos, es no a penas la de colaborar con la eficiencia en la redacción y aplicación de aquellos derechos, sino también la de colaborar con una exposición de todo lo 
que puede ser una dimensión de la dignidad humana. Consciente de que la dignidad es una idea controvertida en los derechos humanos, propongo debatir no únicamente como la literatura puede ayudarnos a definir lo que puede significar la dignidad - una perspectiva común en la crítica literaria a la luz de los derechos humanos -, sino como aquella puede ayudarnos a considerar la hipótesis de que en la imposibilidad de definir el concepto de dignidad existe, en verdad, una buena premisa para que los derechos humanos sean defendidos.

Palabras clave: derechos humanos; crítica literaria comprometida; Segunda Guerra Mundial; historia y memoria; empatía. 